\title{
A New Xanthone Glycoside from the Endolichenic Fungus Sporormiella irregularis
}

\author{
Bin-Jie Yang ${ }^{1}$, Guo-Dong Chen ${ }^{2, *}$, Yan-Jun $\mathrm{Li}^{2}{ }^{2}$, Dan $\mathrm{Hu}^{2}$, Liang-Dong Guo ${ }^{3}$, Ping Xiong ${ }^{1, *}$ \\ and Hao Gao ${ }^{2}$ \\ 1 Department of Pharmaceutical Engineering, College of Materials and Energy, \\ South China Agricultural University, Guangzhou 510640, China; 15920520642@163.com \\ 2 Institute of Traditional Chinese Medicine \& Natural Products, College of Pharmacy, Jinan University, \\ Guangzhou 510632, China; Liyanjun1014@163.com (Y.-J.L.); thudan@jnu.edu.cn (D.H.); \\ tghao@jnu.edu.cn (H.G.) \\ 3 State Key Laboratory of Mycology, Institute of Microbiology, Chinese Academy of Sciences, \\ Beijing 100190, China; guold@sun.im.ac.cn \\ * Correspondence: chgdtong@163.com (G.-D.C.); xp0000542003@scau.edu.cn (P.X.); \\ Tel.: +86-20-852-215-59 (G.-D.C.); +86-135-333-857-89 (P.X.)
}

Academic Editor: Derek J. McPhee

Received: 14 April 2016; Accepted: 4 June 2016; Published: 11 June 2016

\begin{abstract}
A new xanthone glycoside, sporormielloside (1), was isolated from an EtOAc extract of an endolichenic fungal strain Sporormiella irregularis (No. 71-11-4-1), along with two known xanthones $(2,3)$. Their structures were determined by detailed spectroscopic analysis (IR, MS, and 1D- and 2D-NMR), a chemical method, and a comparison of NMR data with closely related compounds previously reported. According to the structures of isolated compounds, their plausible biosynthetic pathway was deduced.
\end{abstract}

Keywords: xanthone glycoside; Sporormiella irregularis; endolichenic fungus; biosynthetic pathway

\section{Introduction}

Sporormiella is a genus belonging to the family of Sporormiaceae with more than 80 species distributed across boreal and temperate regions of the world [1-4]. Some species of the genus are saprobes, and others are endophytic in living plants, fungi, and lichens [5-8]. Previous chemical investigation of this genus led to isolation of polyketides (such as xanthones (sporormiellins A-C, sporormiellones A, B, microsphaeropsone A, brocaenol B) [5,9], chromones (corymbiferone $\mathrm{C}$, corymbiferan lactone E, corymbiferone) [5], macrocyclic lactone (sporostatin) [10], organic acids (including zaragozic acid B, L731-127, L731-128, sporovexins A, B, and sporminarins A, B) [11-13]), triterpenoids (including FR171456, FR173945 [14,15], and $\left(2 \mathrm{a} R, 2 \mathrm{a}^{1} R, 3 S, 5 \mathrm{a} R, 6 \mathrm{~b} S, 9 S, 10 \mathrm{a} R, 12 \mathrm{~b} S\right)-9-$ hydroxy-2a ${ }^{1}, 3,6 b, 10,10,12 b$-hexamethyl-1,2,2a, $2 a^{1}, 3,5 a, 6,6 b, 7,8,9,10,10 a, 11,12,12 b$-hexadecahydro- $4 H$ cyclopenta[de]naphtho[2,1-g]chromen-4-one [16]), steroids (including 22E-3,7-epoxy-5,10:8,9disecoergosta-9(10),22-diene-5,8-dione, $22 E-5 \alpha, 6 \alpha$-epoxyergosta-8(14),22-diene-3 $\beta, 7 \alpha$-diol, $22 E-5 \alpha, 6 \alpha$ epoxyergosta-8(9),22-diene-3 $\beta, 7 \alpha$-diol, $\quad 22 E-7 \alpha$-methoxy- $5 \alpha, 6 \alpha$-epoxyergosta- $8(14), 22$-dien-3 $\beta$-ol, $22 E$-3 $\beta$-hydroxy- $5 \alpha, 6 \alpha$-epoxyergosta-22-en-7-one, $22 E$-ergosta-7,22-diene- $3 \beta, 5 \alpha, 6 \beta$-triol, $22 E-6 \beta$ methoxyergosta-7,22-diene- $3 \beta, 5 \alpha$-diol, $22 E-5 \alpha, 8 \alpha$-epidioxyergosta-6,22-dien-3 $\beta$-ol and 22E-ergosta4,6,8(14),22-tetraen-3-one [17]), and the nitrogenous compounds (including terezines A-D [18], similin B [19], sporovexin C [12], and (2Z,4E,6E)-3-hydroxy- $N-(1,11 a, 11 b$-trihydroxy-3,6,9trioxodecahydro-1H-pyrazino[1,2-a]pyrrolo[2,1-c]pyrazin-10-yl)octadeca-2,4,6-trienamide [20]).

In our previous chemical investigation of this genus Sporormiella, a series of xanthones (sporormiellins A-C, sporormiellones A, B, and microsphaeropsone A) were isolated from S. minima 
(No. 66-3-4-2) [9]. Notably, sporormiellin A is the first discovered tetrahydrofuran-fused furochromone with an unprecedented tetracyclic skeleton. As a part of our continuing search for more xanthones, a chemical investigation of another species (S. irregularis (No. 71-11-4-1)) from this genus was carried out, which led to isolation of a new xanthone glycoside, sporormielloside (1), along with two known biogenetically related compounds, calyxanthone-8-methyl ether (2) and endocrocin (3). Compound 2 is a known compound; however, there is no reference reporting its NMR data. Therefore, the details of the isolation and structural elucidation of these isolated compounds are reported herein.

\section{Results and Discussion}

Compound 1 was obtained as a yellow amorphous powder. The quasi-molecular ion at $m / z 451.1240[\mathrm{M}+\mathrm{H}]^{+}$by HRESIMS indicated the molecular formula of $\mathbf{1}$ was $\mathrm{C}_{21} \mathrm{H}_{22} \mathrm{O}_{11}$ with 11 degrees of unsaturation. The ${ }^{1} \mathrm{H}-\mathrm{NMR}$ spectrum (DMSO- $d_{6}$, Figure S1) displayed six exchangeable protons $\left(\delta_{\mathrm{H}} 11.76\left(1 \mathrm{H}\right.\right.$, br s), $11.64(1 \mathrm{H}$, br s $), 5.14\left(1 \mathrm{H}, \mathrm{d}, J=4.9 \mathrm{~Hz}, 2^{\prime}-\mathrm{O} \underline{\mathrm{H}}\right), 5.01(1 \mathrm{H}, \mathrm{d}, J=4.8 \mathrm{~Hz}$, $\left.3^{\prime}-\mathrm{OH}\right), 4.92\left(1 \mathrm{H}, \mathrm{d}, J=5.1 \mathrm{~Hz}, 4^{\prime}-\mathrm{O} \underline{\mathrm{H}}\right)$, and $\left.4.26\left(1 \mathrm{H}, \mathrm{t}, J=5.6 \mathrm{~Hz}, 6^{\prime}-\mathrm{O} \underline{\mathrm{H}}\right)\right)$, three aromatic protons $\left(\delta_{\mathrm{H}} 6.92(1 \mathrm{H}\right.$, br s, H-3), $6.65(1 \mathrm{H}, \mathrm{br} \mathrm{s}, \mathrm{H}-15)$, and $6.58(1 \mathrm{H}, \mathrm{s}, \mathrm{H}-7))$, five $\mathrm{sp}^{3}$ methine protons (including one anomeric proton $\left.\delta_{\mathrm{H}} 4.84\left(1 \mathrm{H}, \mathrm{d}, J=7.6 \mathrm{~Hz}, \mathrm{H}-1^{\prime}\right)\right)$, one sp $\mathrm{s}^{3}$ methylene group $\left(\delta_{\mathrm{H}} 3.60(1 \mathrm{H}\right.$, ddd, $\left.J=11.6,5.6,1.8 \mathrm{~Hz}, \mathrm{H}-6^{\prime} \mathrm{a}\right)$ and $\left.3.39\left(1 \mathrm{H}, \mathrm{ddd}, J=11.6,5.8,5.6 \mathrm{~Hz}, \mathrm{H}-6^{\prime} \mathrm{b}\right)\right)$, and two methyl groups $\left(\delta_{\mathrm{H}} 3.92\left(3 \mathrm{H}, \mathrm{s}, 8-\mathrm{OCH}_{3}\right), 2.39\left(3 \mathrm{H}\right.\right.$, br s, H-1)). The ${ }^{13} \mathrm{C}-\mathrm{NMR}$ and DEPT-135 spectra (Figure S2) of 1 showed 21 carbon signals including a ketone carbonyl $\left(\delta_{C} 183.6\right)$, twelve aromatic carbons $\left(\delta_{C} 160.1,159.9,157.6,155.5,149.3,148.5,125.1,111.2,107.9,104.7,101.3\right.$, and 95.5), two methyl carbons (including one oxygenated $\left.\left(\delta_{C} 56.7\right)\right)$, and a set of hexose moiety carbons $\left(\delta_{C} 103.6,77.3,76.5,74.2,69.9\right.$, and 61.1). According to the analysis of coupling constants $\left({ }^{3} J_{\mathrm{H}-2^{\prime}, \mathrm{H}-3^{\prime}}=8.6 \mathrm{~Hz},{ }^{3} J_{\mathrm{H}-3^{\prime}, \mathrm{H}-4^{\prime}}=8.6 \mathrm{~Hz}\right.$, and ${ }^{3} \mathrm{~J}_{\mathrm{H}-4^{\prime}, \mathrm{H}-5^{\prime}}=9.6 \mathrm{~Hz}$ ), the analysis of ${ }^{1} \mathrm{H}-{ }^{1} \mathrm{H}$ COSY (Figure 1), and a comparison with the previously reported $[21,22]{ }^{13} \mathrm{C}-\mathrm{NMR}$ data of the glucopyranoside unit, the hexose moiety of $\mathbf{1}$ was identified as glucopyranoside (Glu). After acid hydrolysis and derivatization of $\mathbf{1}$, the HPLC analysis revealed the presence of D-glucoses and compared them with derivatives obtained by the same method with standard monosaccharides [23]. The Glu unit in $\mathbf{1}$ was attached to the aglycone via a $\beta$-linkage on the basis of the coupling constant of the anomeric proton located at $\delta_{\mathrm{H}} 4.84(1 \mathrm{H}, \mathrm{d}, J=7.6 \mathrm{~Hz}$, $\left.\mathrm{H}-1^{\prime}\right)$. The connection position of Glu unit to aglycone was established at C-9 on the basis of the HMBC correlation from H-1' to C-9. Combined with the molecular formula and chemical shifts of ${ }^{1} \mathrm{H}$ and ${ }^{13} \mathrm{C}$, the structure of aglycone was established based on the key HMBC correlations from H-1 to C-2/C-3/C-15, from H-3 to C-4/C-12/C-13/C-15, from H-15 to C-3/C-13/C-14, from H-7 to C-6/C-8/C-9/C-11/C-12, from 8-OC $\underline{H}_{3}$ to C-8, and the key ROESY correlations between 8-OC $\underline{H}_{3}$ and $\mathrm{H}-7 / \mathrm{H}_{-1}^{\prime}$ (as shown in Figure 1). Therefore, the structure of $\mathbf{1}$ was elucidated as shown in Figure 2, which was a new xanthone glycoside called sporormielloside. The assignments of all proton and carbon resonances are provided in Table 1.

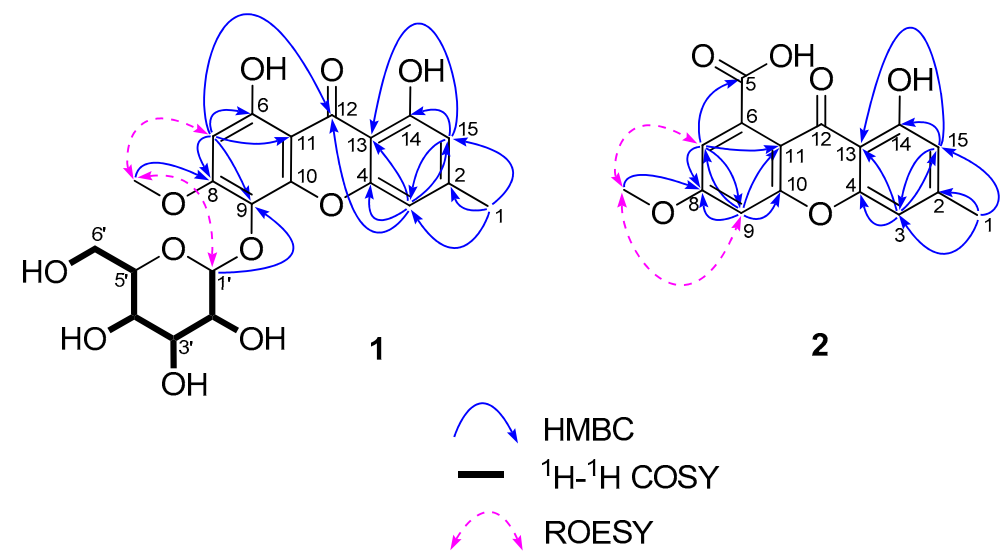

Figure 1. Key ${ }^{1} \mathrm{H}_{-}{ }^{1} \mathrm{H}$ COSY, HMBC and ROESY correlations of $\mathbf{1}$ and $\mathbf{2}$. 

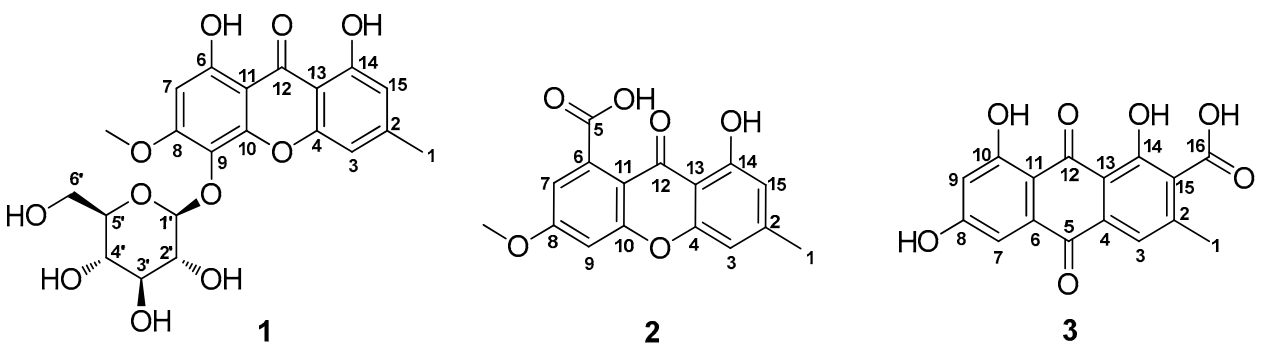

Figure 2. Chemical structures of $\mathbf{1}-\mathbf{3}$.

Table 1. The ${ }^{1} \mathrm{H}-\mathrm{NMR}(400 \mathrm{MHz})$ and ${ }^{13} \mathrm{C}-\mathrm{NMR}(100 \mathrm{MHz})$ data of compound 1 (in DMSO- $\left.d_{6}\right)$.

\begin{tabular}{|c|c|c|c|c|c|}
\hline \multirow{2}{*}{ No. } & \multicolumn{5}{|c|}{1} \\
\hline & $\delta_{C}$, Mult & $\delta_{\mathrm{H}}$, Mult, $(J$ in $\mathrm{Hz})$ & ${ }^{1} \mathrm{H}-{ }^{1} \mathrm{H} \cos Y$ & НМВС & ROESY \\
\hline 1 & $21.9, \mathrm{CH}_{3}$ & $2.39, \mathrm{br} \mathrm{s}$ & 3,15 & $2,3,15$ & \\
\hline 2 & 149.3, qC & & & & \\
\hline 3 & 107.9, CH & $6.92, \mathrm{br} \mathrm{s}$ & 1,15 & $1,4,12,13,15$ & \\
\hline 4 & $155.5, \mathrm{qC}$ & & & & \\
\hline 6 & 157.6, qC & & & & \\
\hline 7 & 95.5, CH & $6.58, \mathrm{~s}$ & & $6,8,9,11,12$ & $8-\mathrm{OCH}_{3}$ \\
\hline 8 & 160.1, qC & & & & \\
\hline 9 & 125.1, qC & & & & \\
\hline 10 & $148.5, \mathrm{qC}$ & & & & \\
\hline 11 & $101.3 \mathrm{qC}$ & & & & \\
\hline 12 & 183.6, qC & & & & \\
\hline 13 & 104.7, qC & & & & \\
\hline 14 & $159.9, \mathrm{qC}$ & & & & \\
\hline 15 & $111.2, \mathrm{CH}$ & $6.65, \mathrm{brs}$ & 1,3 & $1,3,13,14$ & \\
\hline $8-\mathrm{OCH}_{3}$ & $56.7, \mathrm{CH}_{3}$ & $3.92, \mathrm{~s}$ & & 8 & $7,1^{\prime}$ \\
\hline $6-\mathrm{OH}^{*}$ & & 11.76 , br s & & & \\
\hline $14-\mathrm{OH}^{*}$ & & 11.64 , br s & & & \\
\hline $1^{\prime}$ & 103.6, CH & $4.84, \mathrm{~d},(7.6)$ & $2^{\prime}$ & 9 & $3^{\prime}, 5^{\prime}, 8-\mathrm{OC}_{3}$ \\
\hline $2^{\prime}$ & $74.2, \mathrm{CH}$ & 3.32 , overlapped & $1^{\prime}, 3^{\prime}, 2^{\prime}-\mathrm{OH}$ & $1^{\prime}, 3^{\prime}, 4^{\prime}$ & \\
\hline $3^{\prime}$ & $76.5, \mathrm{CH}$ & $3.24, \mathrm{td},(8.6,4.8)$ & $2^{\prime}, 4^{\prime}, 3^{\prime}-\mathrm{O} \underline{\bar{H}}$ & $2^{\prime}, 4^{\prime}$ & $1^{\prime}, 5^{\prime}$ \\
\hline $4^{\prime}$ & 69.9, $\mathrm{CH}$ & $3.16, \mathrm{~m}$ & $3^{\prime}, 5^{\prime}, 4^{\prime}-\mathrm{OH}$ & $3^{\prime}, 5^{\prime}, 6^{\prime}$ & \\
\hline $5^{\prime}$ & 77.3, $\mathrm{CH}$ & 3.09, ddd, $(9.6,5.8,1.8)$ & $4^{\prime}, 6^{\prime} \mathrm{a}, 6^{\prime} \mathrm{b}$ & $1^{\prime}, 4^{\prime}$ & $1^{\prime}, 3^{\prime}$ \\
\hline $6^{\prime}$ & $61.1, \mathrm{CH}_{2}$ & $3.60, \mathrm{ddd},(11.6,5.6,1.8)$, a & $5^{\prime}, 6^{\prime} \mathrm{b}, 6^{\prime}-\mathrm{OH}$ & & \\
\hline $2,-\mathrm{OH}$ & & 3.39, ddd, $(11.6,5.8,5.6), \mathrm{b}$ & $5^{\prime}, 6^{\prime} \mathrm{a}, 6^{\prime}-\mathrm{O} \underline{\overline{\mathrm{H}}}$ & & \\
\hline $3^{\prime}-\mathrm{OH}$ & & $5.14, \mathrm{~d},(4.9)$ & $\begin{array}{l}2^{\prime} \\
3^{\prime}\end{array}$ & & \\
\hline $4^{\prime}-\mathrm{OH}$ & & $\begin{array}{l}5.01, d,(4.8) \\
4.92, d,(5.1)\end{array}$ & $\begin{array}{l}3 \\
4^{\prime}\end{array}$ & & \\
\hline $6^{\prime}-\mathrm{OH}$ & & $4.26, t,(5.6)$ & $6^{\prime} \mathrm{a}, 6^{\prime} \mathrm{b}$ & & \\
\hline
\end{tabular}

Compound 2 was obtained as a yellowish amorphous powder. The quasi-molecular ion at $m / z 323.0527[\mathrm{M}+\mathrm{Na}]^{+}$by HRESIMS indicated the molecular formula of 2 was $\mathrm{C}_{16} \mathrm{H}_{12} \mathrm{O}_{6}$ with 11 degrees of unsaturation. The ${ }^{1} \mathrm{H}-\mathrm{NMR}$ spectrum (DMSO- $d_{6}$, Figure S7) displayed two exchangeable protons $\left(\delta_{\mathrm{H}} 13.23(1 \mathrm{H}, \mathrm{br} \mathrm{s}), 12.33(1 \mathrm{H}, \mathrm{brs})\right)$, four aromatic protons $\left(\delta_{\mathrm{H}} 7.20(1 \mathrm{H}\right.$, $\mathrm{d}, J=2.4 \mathrm{~Hz}, \mathrm{H}-9), 6.99(1 \mathrm{H}, \mathrm{d}, J=2.4 \mathrm{~Hz}, \mathrm{H}-7), 6.88(1 \mathrm{H}, \mathrm{br} \mathrm{s}, \mathrm{H}-3)$, and $6.67(1 \mathrm{H}, \mathrm{br} \mathrm{s}, \mathrm{H}-15))$, and two sp ${ }^{3}$ methyl groups $\left(\delta_{\mathrm{H}} 3.96\left(3 \mathrm{H}, \mathrm{s}, 8-\mathrm{OCH}_{3}\right), 2.41(3 \mathrm{H}, \mathrm{s}, \mathrm{H}-1)\right)$. The ${ }^{13} \mathrm{C}-\mathrm{NMR}$ and DEPT-135 spectra (Figure S8) showed 16 signals, assigned two carbonyl carbons (a ketone one $\left(\delta_{C} 179.2\right)$ and a carboxylic acid/ester one $\left.\left(\delta_{C} 168.8\right)\right)$, twelve $\mathrm{sp}^{2}$ aromatic carbons, and two methyl carbons (including an oxygenated one $\left.\left(\delta_{C} 56.6\right)\right)$. Combined with the molecular formula and chemical shifts of ${ }^{1} \mathrm{H}$ and ${ }^{13} \mathrm{C}$, the key HMBC correlations from $\mathrm{H}-1$ to C-2/C-3/C-15, from H-3 to C-4/C-13/C-15, from H-15 to C-3/C-13/C-14, from H-7 to C-5/C-8/C-9/C-11, from H-9 to C-7/C-8/C-10/C-11, from 8-OC H $_{3}$ to C-8, and the key ROESY correlations between 8-OCH${ }_{3}$ and $\mathrm{H}-7 / \mathrm{H}-9$ (as shown in Figure 1) established the planar structure of $\mathbf{2}$, which was a methyl esterified derivative of calyxanthone [24] at C-8. Therefore, the structure of $\mathbf{2}$ was elucidated as the same as that of the known compound (calyxanthone-8-methyl ether). The assignments of NMR data of $\mathbf{2}$ are provided in Table 2. 
Table 2. The ${ }^{1} \mathrm{H}-\mathrm{NMR}(400 \mathrm{MHz})$ and ${ }^{13} \mathrm{C}-\mathrm{NMR}(100 \mathrm{MHz})$ data of 2 (in DMSO- $\left.d_{6}\right)$.

\begin{tabular}{|c|c|c|c|c|c|}
\hline \multirow[b]{2}{*}{ No. } & \multicolumn{5}{|c|}{2} \\
\hline & $\delta_{C}$, Mult & $\delta_{\mathrm{H}}$, Mult, $(J$ in $\mathrm{Hz})$ & ${ }^{1} \mathrm{H}^{-1} \mathrm{H}$ COSY & HMBC & ROESY \\
\hline 1 & $21.9, \mathrm{CH}_{3}$ & 2.41, br s & 3,15 & $2,3,15$ & \\
\hline 2 & $148.8, \mathrm{qC}$ & & & & \\
\hline 3 & $107.2, \mathrm{CH}$ & $6.88, \mathrm{br} \mathrm{s}$ & 1,15 & $1,4,13,15$ & \\
\hline 4 & 155.2, qC & & & & \\
\hline 5 & $168.8, \mathrm{qC}$ & & & & \\
\hline 6 & $136.5, \mathrm{qC}$ & & & & \\
\hline 7 & $111.8, \mathrm{CH}$ & $6.99, \mathrm{~d},(2.4)$ & 9 & $5,8,9,11$ & $8-\mathrm{OC} \underline{H}_{3}$ \\
\hline 8 & $164.8, \mathrm{qC}$ & & & & \\
\hline 9 & $101.2, \mathrm{CH}$ & $7.20, \mathrm{~d},(2.4)$ & 7 & $7,8,10,11$ & $8-\mathrm{OC} \underline{H}_{3}$ \\
\hline 10 & 157.6, qC & & & & \\
\hline 11 & 109.7, qC & & & & \\
\hline 12 & $179.2, \mathrm{qC}$ & & & & \\
\hline 13 & $105.9, \mathrm{qC}$ & & & & \\
\hline 14 & $160.5, \mathrm{qC}$ & & & & \\
\hline 15 & $111.2, \mathrm{CH}$ & 6.67, br s & 1,3 & $1,3,13,14$ & \\
\hline $8-\mathrm{OCH}_{3}$ & 56.6, $\mathrm{CH}_{3}$ & $3.96, \mathrm{~s}$ & & 8 & 7,9 \\
\hline $5-\mathrm{OH}^{*}$ & & 13.23, br s & & & \\
\hline $14-\mathrm{OH}^{*}$ & & 12.33, br s & & & \\
\hline
\end{tabular}

Compound 3 was obtained as a yellow amorphous powder. The quasi-molecular ion at $m / z 313.0345[\mathrm{M}-\mathrm{H}]^{-}$by HRESIMS indicated the molecular formula of 3 was $\mathrm{C}_{16} \mathrm{H}_{10} \mathrm{O}_{7}$ with 12 degrees of unsaturation. The ${ }^{1} \mathrm{H}-\mathrm{NMR}$ and ${ }^{13} \mathrm{C}-\mathrm{NMR}$ spectrum (DMSO- $d_{6}$ ) are the same as that of endocrocin [25].

Based on the structural features of compounds 1-3, the plausible biosynthetic pathway of them was deduced (Scheme 1). The $\mathrm{C}_{16}$-octaketide produced by non-reducing polyketide synthase undergoes cyclization to yield atrochryone carboxylic acid [26], which is either autoxidized to endocrocin (3) or undergoes dehydration first followed by decarboxylation and spontaneous oxidation to give emodin $[27,28]$. The resulting emodin will be enzymatically transformed into intermediate a by oxidative ring opening between C-4 and C-5 [26,29], and subsequent dehydration will give intermediate $\mathbf{b}$. Compound $\mathbf{2}$ may be derived from intermediate $\mathbf{b}$ via methylation. After decarboxylation and oxidation, intermediate $\mathbf{b}$ may transform into intermediate $\mathbf{c}$, and $\mathbf{1}$ may be derived from intermediate $\mathbf{c}$ via methylation and glycosylation [26].

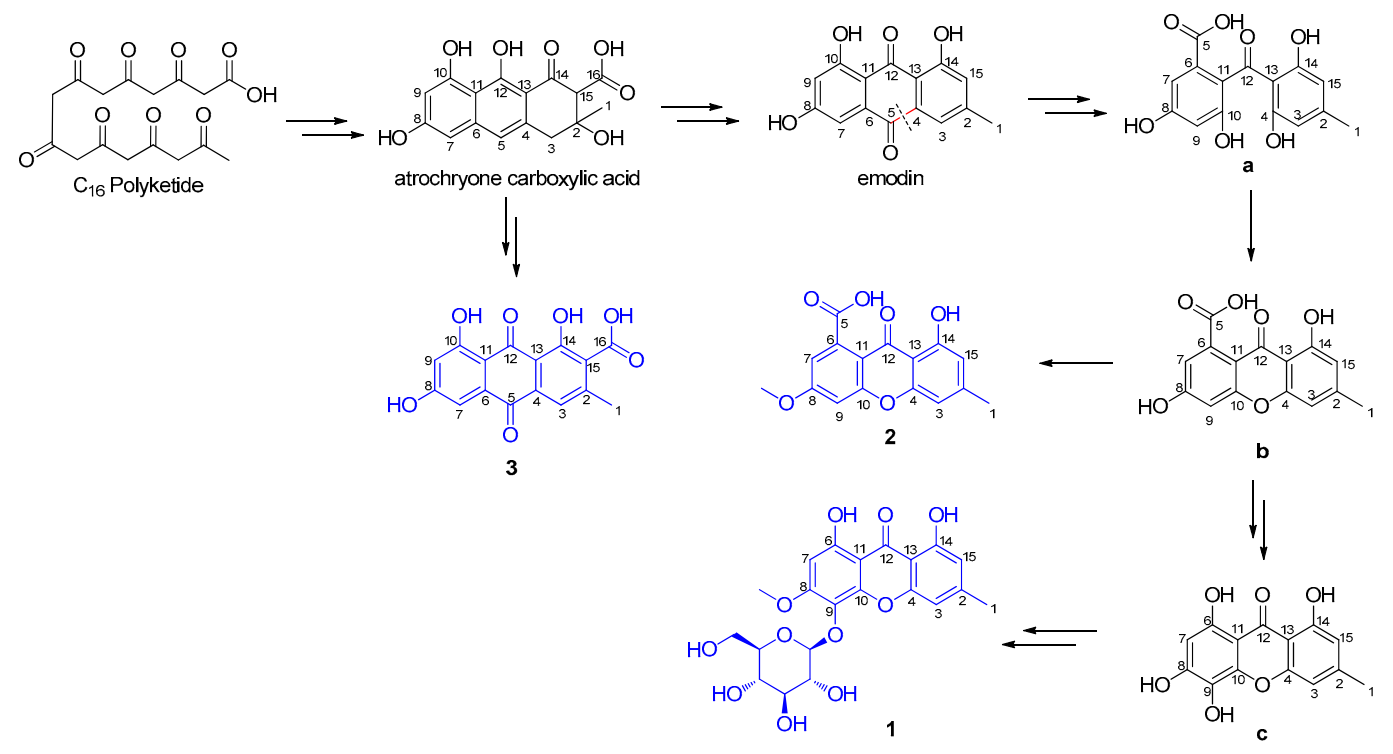

Scheme 1. The plausible biosynthetic pathway of $1-3$. 


\section{Materials and Methods}

\subsection{Chemicals}

L-cysteine methyl ester hydrochloride, $o$-tolyl isothiocyanate, D-glucose (D-Glc), L-glucose (L-Glc), and DMSO- $d_{6}$ were purchased from Sigma-Aldrich Chemical Co. Ltd. (Saint Louis, MO, USA). Methanol $(\mathrm{MeOH})$ was purchased from Yuwang Industrial Co. Ltd. (Yucheng, China). Formic acid $(\mathrm{HCOOH})$ was obtained from Kemiou Chemical Reagent Co. Ltd. (Tianjin, China).

\subsection{General Experimental Procedures}

UV data were recorded using a JASCO V-550 UV/vis spectrometer (Jasco International Co. Ltd., Tokyo, Japan). IR data were recorded on a JASCO FT/IR-480 plus spectrometer (Jasco International Co. Ltd.). Optical rotations were measured on a JASCO P1020 digital polarimeter (Jasco International Co. Ltd.). The ESIMS spectra were performed on a Bruker amaZon SL mass spectrometer (Bruker Daltonics Int., Boston, MA, USA), and the HRESIMS spectra were obtained on a Waters Synapt G2 mass spectrometer (Waters Corporation, Milford, MA, USA). 1D and 2D NMR spectra were acquired with Bruker AV 400 spectrometers (Bruker BioSpin Group, Faellanden, Switzerland) using the solvent signals (DMSO- $d_{6}: \delta_{\mathrm{H}} 2.50 / \delta_{\mathrm{C}} 39.5$ ) as internal standards. The analytical HPLC was performed on a Dionex HPLC system equipped with an Ultimate 3000 pump, an Ultimate 3000 DAD, an Ultimate 3000 Column Compartment, an Ultimate 3000 autosampler (Thermo Fisher Scientific Inc., Sunnyvale, CA, USA), and an Alltech (Grace) 2000ES evaporative light scattering detector (Alltech International Inc., Vienna, VA, USA) using a Phenomenex Gemini $C_{18}$ column $(4.6 \mathrm{~mm} \times 250 \mathrm{~mm}, 5 \mu \mathrm{m})$ (Phenomenex Inc., Los Angeles, CA, USA). Semi-preparative HPLC was performed on a Dionex HPLC system, which was equipped with an Ultimate 3000 pump, and an Ultimate 3000 RS variable wavelength detector using a Phenomenex Gemini $C_{18}$ column $(10.0 \mathrm{~mm} \times 250 \mathrm{~mm}, 5 \mu \mathrm{m})$ (Phenomenex Inc.). The medium pressure liquid chromatography (MPLC) was performed on ODS (60-80 $\mu \mathrm{m}$, YMC Co. Ltd., Tokyo, Japan) and equipped with a dual pump gradient system, a UV preparative detector, and a Dr Flash II fraction collector system (Lisui E-Tech Co. Ltd., Shanghai, China). The organic solvent was evaporated with an EYELA rotary evaporator N-1100 system (Tokyo Rikakikai Co. Ltd., Shanghai, China).

\subsection{Fungus Material}

The strain numbered as 71-11-4-1 was isolated from the lichen Usnea mutabilis Stirt, which was collected in Zixishan Mountain, Yunnan province, China, in November 2006. The strain was identified as S. irregularis based on the morphological characters by one of our authors (L.-D.G.). The fungal strain was cultured on slants of potato dextrose agar (PDA) at $25^{\circ} \mathrm{C}$ for 5 days. Agar plugs were used to inoculate nine Erlenmeyer flasks $(250 \mathrm{~mL})$, each containing $100 \mathrm{~mL}$ of potato dextrose broth (PDB). The nine flasks of the inoculated media were incubated at $25{ }^{\circ} \mathrm{C}$ on a rotary shaker at $200 \mathrm{rpm}$ for five days to prepare the seed culture. Fermentation was carried out in 30 Erlenmeyer flasks (500 mL), each containing $70 \mathrm{~g}$ of rice. Distilled $\mathrm{H}_{2} \mathrm{O}(105 \mathrm{~mL})$ was added to each flask, and the rice was soaked overnight before autoclaving at $121^{\circ} \mathrm{C}$ for $30 \mathrm{~min}$. After cooling to room temperature, each flask was inoculated with $10 \mathrm{~mL}$ of the spore inoculum and incubated at $25^{\circ} \mathrm{C}$ for 40 days.

\subsection{Extraction and Isolation}

The culture was extracted four times with EtOAc, and the organic solvent was evaporated in a vacuum to afford the dry crude extract (29.05 g). The crude extract was dissolved in $90 \% v / v$ aqueous $\mathrm{MeOH}(500 \mathrm{~mL})$ and partitioned against the same volume of cyclohexane to afford a cyclohexane fraction (C, $13.42 \mathrm{~g}$ ) and an aqueous $\mathrm{MeOH}$ fraction $(\mathrm{W}, 12.38 \mathrm{~g})$. The aqueous $\mathrm{MeOH}$ fraction $(\mathrm{W}, 12.38 \mathrm{~g})$ was separated by MPLC eluting with $\mathrm{MeOH}-\mathrm{H}_{2} \mathrm{O}(30: 70,50: 50,70: 30$, and 100:0, v/v) to afford four fractions (W1 to W4). Fraction W3 (753.4 mg) was further separated by MPLC with a gradient of $\mathrm{MeOH}-\mathrm{H}_{2} \mathrm{O}$ to yield 9 subfractions (W3a-W3i) and 1 (11.7 mg). Fraction W2 (1.14 g) was further separated by MPLC with a gradient of $\mathrm{MeOH}-\mathrm{H}_{2} \mathrm{O}$ to yield 19 subfractions (W2a to 
W2s). Subfraction W2m (50.0 mg) was purified by semi-preparative HPLC with $\mathrm{MeOH}-\mathrm{H}_{2} \mathrm{O}-\mathrm{HCOOH}$ $(80: 20: 0.1, v / v)$ at a flow rate of $3 \mathrm{~mL} / \mathrm{min}$ to yield $2(4.0 \mathrm{mg})$. Subfraction W2i $(66.1 \mathrm{mg})$ was purified with semi-preparative $\mathrm{HPLC}$ using $\mathrm{MeOH}-\mathrm{H}_{2} \mathrm{O}-\mathrm{HCOOH}(60: 40: 0.1, v / v)$ at flow rate of $3 \mathrm{~mL} / \mathrm{min}$ to yield $3(9.0 \mathrm{mg})$.

Sporormielloside (1) (Figure 2): Yellow amorphous powder; $[\alpha]_{\mathrm{D}}^{25}=-46.3\left(c=0.08, \mathrm{CHCl}_{3}-\mathrm{MeOH}=1: 2\right)$; UV (MeOH) $\lambda_{\max }(\log \varepsilon) 206$ (4.66), 232 (4.24), 256 (4.42), 336 (4.13) nm; IR (KBr) $v_{\max }$ 3421, 2906, 2360, 2339, 1632, 1608, 1515, 1370, 1267, 1209, 1160, 1122, 1071, 1024, $552 \mathrm{~cm}^{-1}$; ESIMS (positive): $m / z 473[\mathrm{M}+\mathrm{Na}]^{+}, 923[2 \mathrm{M}+\mathrm{Na}]^{+}$; HRESIMS (positive): $\mathrm{m} / z 451.1240[\mathrm{M}+\mathrm{H}]^{+}\left(\right.$calcd. for $\mathrm{C}_{21} \mathrm{H}_{23} \mathrm{O}_{11}$, 451.1240); ${ }^{1} \mathrm{H}$ - and ${ }^{13} \mathrm{C}-\mathrm{NMR}$ data see Table 1.

Calyxanthone-8-methyl ether (2) (Figure 2): Yellowish amorphous powder; $U V(\mathrm{MeOH}) \lambda_{\max }(\log \varepsilon)$ 202 (4.53), 236 (4.62), 251 (4.51), 302 (4.37) 351 (3.96) nm; IR (KBr) $v_{\max }$ 3446, 3248, 2360, 2335, 1739, 1650, 1600, 1571, 1504, 1455, 1423, 1394, 1273, 1217, 1179, 1154, 1128, 1016, 829, $687 \mathrm{~cm}^{-1}$; ESIMS (positive): $m / z 301\left[\mathrm{M}+\mathrm{H}^{+}, 323[\mathrm{M}+\mathrm{Na}]^{+}\right.$; ESIMS (negative) $\mathrm{m} / z 299[\mathrm{M}-\mathrm{H}]^{-}, 255[\mathrm{M}-\mathrm{COOH}]^{-}$; HRESIMS (positive): $m / z 323.0527$ [M + Na] ${ }^{+}$(calcd. for $\mathrm{C}_{16} \mathrm{H}_{12} \mathrm{O}_{6} \mathrm{Na}, 323.0532$ ); ${ }^{1} \mathrm{H}$ - and ${ }^{13} \mathrm{C}-\mathrm{NMR}$ data see Table 2.

Endocrocin (3) (Figure 2): Yellow amorphous powder; UV (MeOH) $\lambda_{\max }(\log \varepsilon) 203(4.55), 226$ (4.65), 375 (3.50), 440 (4.26) nm; IR (KBr) $v_{\max } 3377,2361,2339,1715,1671,1622,1384,1255,1206,1171$, $756 \mathrm{~cm}^{-1}$; ESIMS (negative) $\mathrm{m} / z 313[\mathrm{M}-\mathrm{H}]^{-}$; HRESIMS (negative): $\mathrm{m} / z 313.0345[\mathrm{M}-\mathrm{H}]^{-}$(calcd. for $\left.\mathrm{C}_{16} \mathrm{H}_{9} \mathrm{O}_{7}, 313.0348\right)$.

\subsection{Acid Hydrolysis}

Acid hydrolysis was performed according to the method described by Tanaka et al. with standard monosaccharides [23]. Compound $\mathbf{1}(1.0 \mathrm{mg})$ was hydrolyzed with $2 \mathrm{M}$ of $\mathrm{HCl}$ for $1 \mathrm{~h}$ at $90{ }^{\circ} \mathrm{C}$. After it was extracted with EtOAc twice, the $\mathrm{H}_{2} \mathrm{O}$ layer was evaporated in vacuo to furnish a monosaccharide residue using a rotary evaporator. The residue was dissolved in pyridine $(1.0 \mathrm{~mL})$ containing L-cysteine methyl ester hydrochloride $(1.0 \mathrm{mg})$ and heated at $60^{\circ} \mathrm{C}$. After $1 \mathrm{~h}, 10 \mu \mathrm{L}$ of $o$-tolyl isothiocyanate was added to the reaction mixture and further reacted at $60^{\circ} \mathrm{C}$ for $1 \mathrm{~h}$. Then, the reaction mixture was directly analyzed by the Dionex HPLC system and detected by an UV detector (at $254 \mathrm{~nm}$ ). Analytical HPLC was performed on the Phenomenex Gemini $\mathrm{C}_{18}$ column with isocratic elution of $\mathrm{CH}_{3} \mathrm{CN}-\mathrm{H}_{2} \mathrm{O}$ $(40: 60, v / v)$ for $40 \mathrm{~min}$ at a flow rate of $0.8 \mathrm{~mL} / \mathrm{min}$. The standard monosaccharides of D-Glc and L-Glc were subjected to the same method.

\section{Conclusions}

Xanthones are commonly found in higher plants, fungi, and lichens [30,31]. However, only eight xanthone aglycones have been isolated from Sporormiella. Xanthone glycosides are mainly isolated from plants such as Gentianaceae and Guttiferae $[32,33]$ but are rarely reported from fungi, except for Phomopsis sp. ZH76 [34], Paecilomyces cinnamomeus BCC 9616 [35], and Aschersonia coffeae Henn. Bcc 28712 [36]. The isolation of sporormielloside (1), which is the first report for xanthone glycoside isolated from Sporormiella. Owing to a lack of any references to calyxanthone-8-methyl ether (2) in the literature, moreover, the assignments of NMR data of $\mathbf{2}$ are provided here for the first time.

Supplementary Materials: Supplementary materials can be accessed at: http://www.mdpi.com/1420-3049/21/ 6/764/s1.

Acknowledgments: This work was supported by National Natural Science Foundation of China (81422054 and 81373306), Guangdong Special Support Program (2014TQ01R420), Guangdong Natural Science Funds for Distinguished Young Scholar (S2013050014287), Guangdong Province Universities and Colleges Pearl River Scholar Funded Scheme (Hao Gao, 2014), and the Science and Technology Program of Guangzhou (2013J4501037, 2014A020210018, and 2015A020209134), China.

Author Contributions: Hao Gao and Ping Xiong initiated and coordinated the project. Bin-Jie Yang, Yan-Jun Li, and Guo-Dong Chen performed the extraction, isolation, and structural identification of the compounds. Liang-Dong Guo and Dan Hu performed the isolation and identification of the fungal strain (No. 71-11-4-1). In addition, Guo-Dong Chen wrote this paper. 
Conflicts of Interest: The authors declare no conflict of interest.

\section{References}

1. Kruys, A.; Wedin, M. Phylogenetic relationships and an assessment of traditionally used taxonomic characters in the Sporormiaceae (Pleosporales, Dothideomycetes, Ascomycota), utilising multi-gene phylogenies. Syst. Biodivers. 2009, 7, 465-478. [CrossRef]

2. Kruys, A.; Eriksson, O.E.; Wedin, M. Phylogenetic relationships of coprophilous Pleosporales (Dothideomycetes, Ascomycota), and the classification of some Bitunicate taxa of unknown position. Mycol. Res. 2006, 110, 527-536. [CrossRef] [PubMed]

3. Wang, H.K.; Aptroot, A.; Crous, P.W.; Hyde, K.D.; Jeewon, R. The polyphyletic nature of Pleosporales: An example from Massariosphaeria based on rDNA and RBP2 gene phylogenies. Mycol. Res. 2007, 111, 1268-1276. [CrossRef] [PubMed]

4. Ahmed, S.I.; Cain, R.F. Revision of the genera Sporormia and Sporormiella. Can. J. Bot. 1972, 50, $419-477$. [CrossRef]

5. Leyte-Lugo, M.; Figueroa, M.; Gonzalez, M.C.; Glenn, A.E.; Gonzalez-Andrade, M.; Mata, R. Metabolites from the endophytic fungus Sporormiella minimoides isolated from Hintonia Latiflora. Phytochemistry 2013, 96, 273-278. [CrossRef] [PubMed]

6. Guo, L.D.; Huang, G.R.; Wang, Y. Seasonal and tissue age influences on endophytic fungi of Pinus tabulaeformis (Pinaceae) in the Dongling Mountains, Beijing. J. Integr. Plant Biol. 2008, 50, 997-1003. [CrossRef] [PubMed]

7. Schulz, B.; Boyle, C.; Draeger, S.; Römmert, A.K.; Krohn, K. Endophytic fungi: A source of novel biologically active secondary metabolites. Mycol. Res. 2002, 106, 996-1004. [CrossRef]

8. Suryanarayanan, T.S.; Kumaresan, V. Endophytic fungi of some halophytes from an estuarine mangrove forest. Mycol. Res. 2000, 104, 1465-1467. [CrossRef]

9. Xiong, H.; Xiao, G.K.; Chen, G.D.; Chen, H.R.; Hu, D.; Li, X.X.; Zhong, S.W.; Guo, L.D.; Yao, X.S.; Gao, H. Sporormiellin A, the first tetrahydrofuran-fused furochromone with an unprecedented tetracyclic skeleton from Sporormiella minima. RSC Adv. 2014, 46, 24295-24299. [CrossRef]

10. Kinoshita, K.; Sasaki, T.; Awata, M.; Takada, M.; Yaginuma, S. Structure of sporostatin (M5032), an inhibitor of cyclic adenosine 3',5'-monophosphate phosphodiesterase. J. Antibiot. 1997, 50, 961-964. [CrossRef] [PubMed]

11. Huang, L.; Lingham, R.B.; Harris, G.H.; Singh, S.B.; Dufresne, C.; Nallin-Omstead, M.; Bills, G.F.; Mojena, M.; Sanchez, M.; Karkas, J.D.; et al. New fungal metabolites as potential antihypercholesterolemics and anticancer agents. Can. J. Bot. 1995, 73, 898-906. [CrossRef]

12. Soman, A.G.; Gloer, J.B.; Koster, B.; Malloch, D. Sporovexins A-C and a new preussomerin analog: Antibacterial and antifungal metabolites from the coprophilous fungus Sporormiella vexans. J. Nat. Prod. 1999, 62, 659-661. [CrossRef] [PubMed]

13. Mudur, S.V.; Gloer, J.B.; Wicklow, D.T. Sporminarins A and B: Antifungal metabolites from a fungicolous isolate of Sporormiella minimoides. J. Antibiot. 2006, 59, 500-506. [CrossRef] [PubMed]

14. Hatori, H.; Shibata, T.; Tsurumi, Y.; Nakanishi, T.; Katsuoka, M.; Ohtsu, Y.; Sakamoto, K.; Takase, S.; Ueda, H.; Hino, M.; et al. FR171456, a novel cholesterol synthesis inhibitor produced by Sporormiella minima No. 15604 I. taxonomy, fermentation, isolation, physico-chemical properties. J. Antibiot. 2004, 57, 253-259. [CrossRef] [PubMed]

15. Hatori, H.; Shibata, T.; Nishikawa, M.; Ueda, H.; Hino, M.; Fujii, T. FR171456, a novel cholesterol synthesis inhibitor produced by Sporormiella minima No. 15604 II. biological activities. J. Antibiot. 2004, 57, 260-263. [CrossRef] [PubMed]

16. Krohn, K.; Ludewig, K.; Jones, P.G.; Doering, D.; Aust, H.J.; Draeger, S.; Schulz, B. Biologically active metabolites from fungi, $2^{1}$ an antifungal and herbicidal lanostane lactone from Sporormiella australis. Nat. Prod. Lett. 1992, 1, 29-32. [CrossRef]

17. Li, Y.; Li, X.; Chen, G.; Gao, H.; Guo, L.; Yao, X. A new disecosteroid from an endolichenic fungal stain Sporormiella irregularis (No.71-11-4-1). J. Shenyan Pharm. Univ. 2012, 29, 678-684, 701.

18. Wang, Y.; Gloer, J.B.; Scott, J.A.; Malloch, D. Terezines A-D: New amino acid-derived bioactive metabolites from the coprophilous fungus Sporormiella teretispora. J. Nat. Prod. 1995, 58, 93-99. [CrossRef] [PubMed] 
19. Weber, H.A.; Swenson, D.C.; Gloer, J.B.; Malloch, D. Similins A and B: new antifungal metabolites from the coprophilous fungus Sporormiella similis. Tetrahedron Lett. 1992, 33, 1157-1160. [CrossRef]

20. Burgess, B.W.; Clapp-Shapiro, W.H.; Giacobbe, R.A.; Harris, G.H.; Mandela, S.; Polishook, J.; Rattray, M.; Thornton, R.A.; Zink, D.L. Antifungal Agent. GB 2315489 A, 4 February 1998.

21. Chen, G.D.; Li, Y.J.; Gao, H.; Chen, Y.; Li, X.X.; Li, J.; Guo, L.D.; Cen, Y.Z.; Yao, X.S. New azaphilones and chlorinated phenolic glycosides from Chaetomium elatum with caspase-3 inhibitory activity. Planta Med. 2012, 78, 1683-1689. [CrossRef] [PubMed]

22. Urbain, A.; Marston, A.; Grilo, L.S.; Bravo, J.; Purev, O.; Purevsuren, B.; Batsuren, D.; Reist, M.; Carrupt, P.A.; Hostettmann, K. Xanthones from Gentianella amarella ssp. acuta with acetylcholinesterase and monoamine oxidase inhibitory activities. J. Nat. Prod. 2008, 71, 895-897. [CrossRef] [PubMed]

23. Tanaka, T.; Nakashima, T.; Ueda, T.; Tomii, K.; Kouno, I. Facile discrimination of aldose enantiomers by reversed-phase HPLC. Chem. Pharm. Bull. 2007, 55, 899-901. [CrossRef] [PubMed]

24. Hanumaiah, T.; Rao, B.K.; Rao, C.P.; Rao, G.S.R.; Rao, J.U.M.; Rao, K.V.J.; Marshall, D.S.; Thomson, R.H. Naphthalenes and naphthoquinones from Ventilago species. Phytochemistry 1985, 24, 1811-1815. [CrossRef]

25. Waser, M.; Lackner, B.; Zuschrader, J.; Muller, N.; Falk, H. An efficient regioselective synthesis of endocrocin and structural related natural anthraquinones starting from emodin. Tetrahedron Lett. 2005, 46, 2377-2380. [CrossRef]

26. Sanchez, J.F.; Entwistle, R.; Hung, J.H.; Yaegashi, J.; Jain, S.; Chiang, Y.M.; Wang, C.C.C.; Oakley, B.R. Genome-based deletion analysis reveals the prenyl xanthone biosynthesis pathway in Aspergillus nidulans. J. Am. Chem. Soc. 2011, 133, 4010-4017. [CrossRef] [PubMed]

27. Roensberg, D.; Debbab, A.; Mandi, A.; Vasylyeva, V.; Boehler, P.; Stork, B.; Engelke, L.; Hamacher, A.; Sawadogo, R.; Diederich, M.; et al. Pro-apoptotic and immunostimulatory tetrahydroxanthone dimers from the endophytic fungus Phomopsis longicolla. J. Org. Chem. 2013, 78, 12409-12425. [CrossRef] [PubMed]

28. Chiang, Y.M.; Szewczyk, E.; Davidson, A.D.; Entwistle, R.; Keller, N.P.; Wang, C.C.C.; Oakley, B.R. Characterization of the Aspergillus nidulans monodictyphenone gene cluster. Appl. Environ. Microbiol. 2010, 76, 2067-2074. [CrossRef] [PubMed]

29. Schätzle, M.A.; Husain, S.M.; Ferlaino, S.; Müller, M. Tautomers of anthrahydroquinones: Enzymatic reduction and implications for chrysophanol, monodictyphenone, and related xanthone biosyntheses. J. Am. Chem. Soc. 2012, 134, 14742-14745.

30. Cardona, M.L.; Fernandez, I.; Pedro, J.R.; Serrano, A. Xanthones from Hypericum reflexum. Phytochemistry 1990, 29, 3003-3006. [CrossRef]

31. Peres, V.; Nagem, T.J.; de Oliveira, F.F. Tetraoxygenated naturally occurring xanthones. Phytochemistry 2000, 55, 683-710. [CrossRef]

32. Maria Carmen, R.I.; Marston, A.; Hostettmann, K. Xanthones and secoiridoid glucosides of Halenia campanulata. Phytochemistry 1992, 31, 1387-1389.

33. Hostettmann, K.; Wagner, H. Xanthone glycosides. Phytochemistry 1977, 16, 821-829. [CrossRef]

34. Huang, Z.; Yang, J.; Lei, F.; She, Z.; Lin, Y. A new xanthone O-glycoside from the mangrove endophytic fungus Phomopsis sp. Chem. Nat. Compd. 2013, 49, 27-30. [CrossRef]

35. Isaka, M.; Palasarn, S.; Kocharin, K.; Hywel-Jones, N. Comparison of the bioactive secondary metabolites from the scale insect pathogens, anamorph Paecilomyces cinnamomeus and teleomorph Torrubiella luteorostrata. J. Antibiot. 2007, 60, 577-581. [CrossRef] [PubMed]

36. Kornsakulkarn, J.; Saepua, S.; Srichomthong, K.; Supothina, S.; Thongpanchang, C. New mycotoxins from the scale insect fungus Aschersonia coffeae Henn. Bcc 28712. Tetrahedron 2012, 68, 8480-8486. [CrossRef]

Sample Availability: Samples of the compounds are not available from the authors. 